International Journal of Engineering \& Technology, 7 (3) (2018) $1791-1794$
International Journal of Engineering \& Technology
SPC
Website: www.sciencepubco.com/index.php/IJET
doi: $10.14419 /$ ijet.v7i3.16097
Research paper

\title{
Web application to measure level of addictive game
}

\author{
Anastasya Latubessy ${ }^{1}$, Ahmad Jazuli ${ }^{1}$ \\ ${ }^{1}$ Department of Informatics Engineering, Universitas Muria Kudus, Indonesia \\ *Corresponding author E-mail: anastasya.latubessy@umk.ac.id
}

\begin{abstract}
Game becomes very popular within all ages. The intensity of someone playing games can influence the behavior of that person. World Health Organization (WHO) is classifying gaming disorder as an addictive behavior disorder. According to psychologists, there are six types of game addiction behavior, such as, Salience, Euphoria, Conflict, Tolerance, Withdrawal, and the last is Relapse and Reinstatement. A person is said to be addicted to the game if it meets at least three of the six types of behavior that exist. The six types of game addiction behavior then modeled using backward chaining algorithm. After that, the model was implemented into the system. Thus this research re-sult a web application to identify game addiction. Now we can measure how many people are affected using this web application.
\end{abstract}

Keywords: Web Application; Game Addiction; Backward Chaining; Algorithm.

\section{Introduction}

Any type of age can play games. There are some reasons people play games such as to reduce stress, eliminate saturation and get pleasure. Human need for comfortable feeling and fun becomes one of the factors that cause game become very popular, both by children and adults. Excessive craze can cause addictive nature. Green and Bavelier states that brain factors are a factor responsible for the occurrence of addiction is a compound neurochemical in a synaptic cleft called dopamine [1].

The Game can be like a double-edged sword, sometimes it can give us a kindness but sometimes it can ruin us. Excessive use of games can have devastating effects on human activities. Especially for the development of children. Latubessy, A and Ahsin, M.N said that the frequency of playing games is very influential on the activity of children in the learning process. The relationship that occurs is a negative correlation where, the higher game addiction then the activity of students in the learning process decreases. With correlation coefficient between game addiction with student activity in learning process equal to -0.413 with sig $=0,023$ (p $<0,05)[2]$. Besides that Latubessy, A and Wijayanti, E states that 18 of the 20 child data tested indicated game addiction. Their study used 20 data samples of children aged between [9] and 12 years, which is means $90 \%$ of children's samples indicate game addiction [3]. Research related to game addiction is also done by Saquib, etc who do research to see the level of game addiction in children in Saudi Arabia [4]. The increasing interest in game users has also been the reason for research on the governance of game theory as in Lefebvre research in 2018[5].

Parental anxiety about their child's game play patterns is one of the reasons for this research. Some questions that arise in the hearts of parents such as whether the pattern of playing children is still in the category of fair or has been said to be excessive. Although there are also educational games as developed in research conducted by Maskeliunas, etc [6]. In determining it the parents are still having trouble. A parent's knowledge of when a child is said to have been addicted to games is still limited. There are no computerized system that can be used to detect game addiction. Therefore this research produces a web-based application that can be used for identify and detect game addiction based on Game Addiction Behavior. The model is identified based on six parameters including Salience, Euphoria, Conflict, Tolerance, Withdrawal, Relapse and reinstatement [3]. These six parameters were modeled using backward chaining. This model has passed the validity test with the Coefficient Cohen's Kappa yields a strong interpretation value of 0.78 . This means the backward chaining model is appropriate for identification case of game addiction levels as well can be used as a model to develop an expert system [7].

In the expert system, there are many models that can be used such as production rule, backward chaining, forward chaining and others. Production rule can be used to identify flood areas. Fiati and Latubessy research uses this model to determine the category of flood prone areas [8]. Yudistira, B., et al. uses Expert System to making sketch for crime investigation purposes. This research adding sketcher knowledge and the result of the system can made sketching reach $85 \%$ of accuracy level[9]. Arif S. N. also uses rule based expert system to detecting damage a computer network system [10].

\section{Research method}

This research using expert system technology by using action research method. This method is selected because at the first phase there will be a research on identification criteria previously done, and from the result of this research it continues to the modeling formulation and design, and then the implementation of expert system to detect game addiction. The research method of web application to detect game addiciton is shown in Figure 1. 


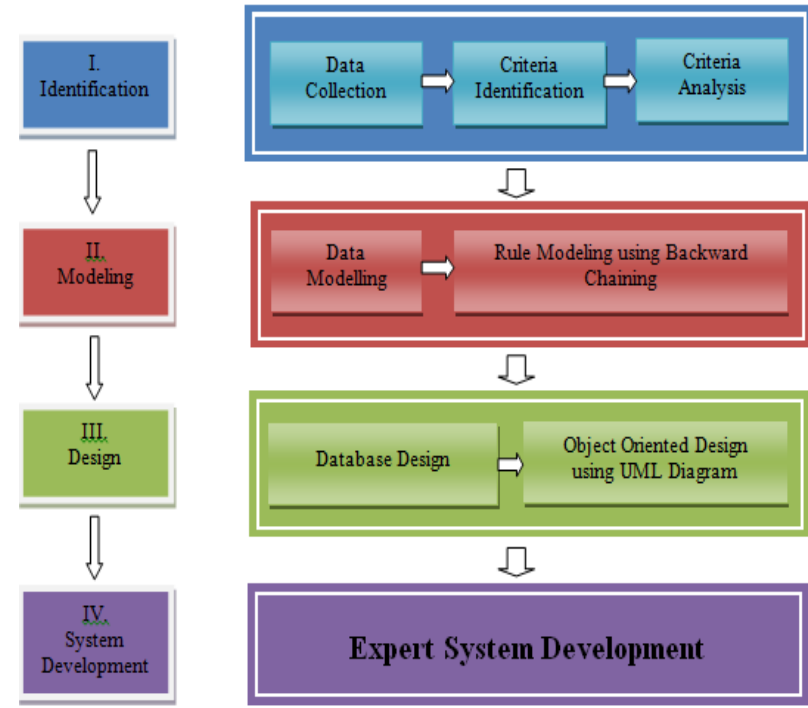

Fig. 1: Research Method of Web Application to Detect Game Addiction.

\section{Result and discussion}

An app has been generated to detect children's game addiction rate using backward chaining algorithm. There are two steps describes here. This section describes the process of Implementation and Testing System.

\subsection{Implementation system}

This research produces a web application to detect children's game addiction that called De-Candu. The Main view of DeCandu shown in Figure 2. That image shows the login menu based on the user level. The user level is divided into three levels, guest user, expert user and admin user.

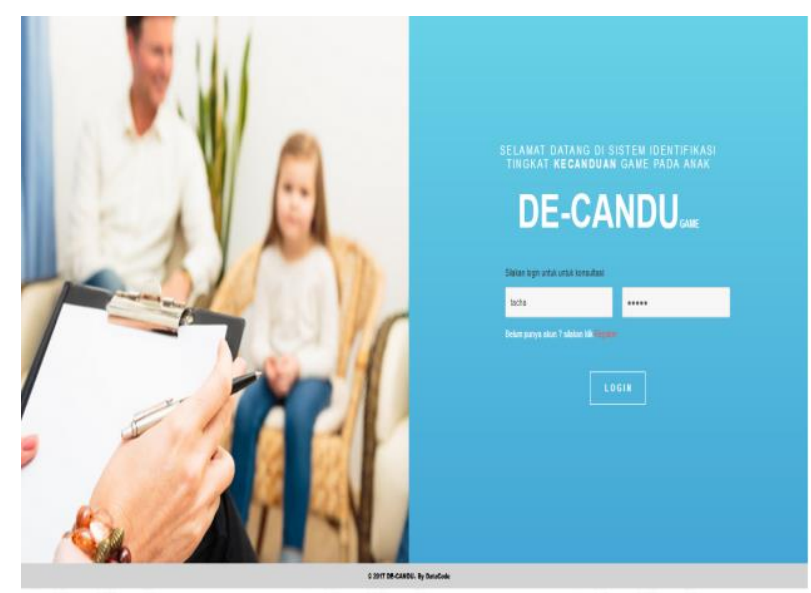

Fig. 2: Main View of Decandu.

While Figure 3 shows an expert user menu. This menu is used by expert user to manage rule, view consultation report and update profile data. In addition an expert user can also manage symptoms of game addiction.

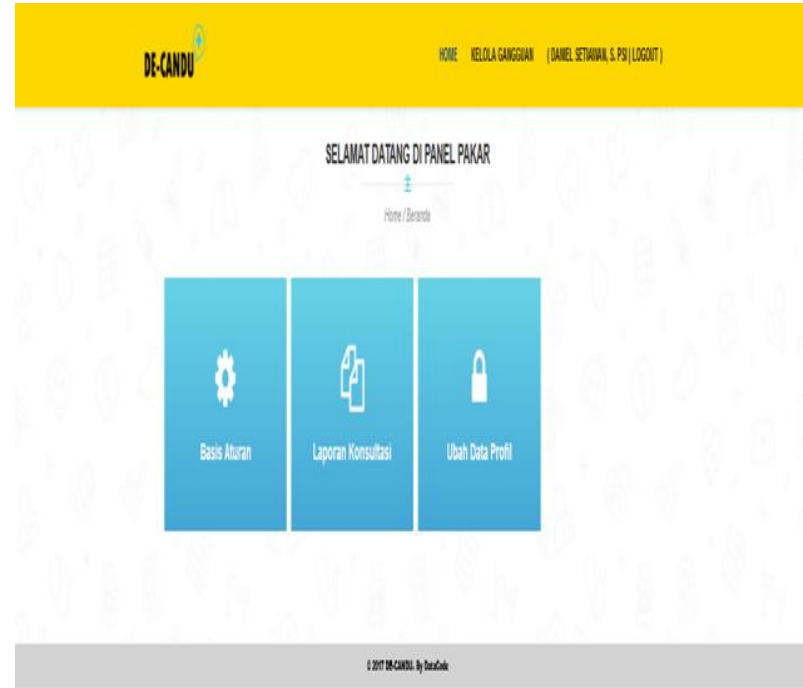

Fig. 3: Expert User Menu.

Next menu is a menu to manage rule of game addiction shown in the Figure 4. There are six parameters that used to identification game adicition such as, Sailence, Euphorial, Conflict, Tolerance, Witdrawal, Relapse and Reinstatement. This rule has been modeled previously through previous research using backward chaining method [3].

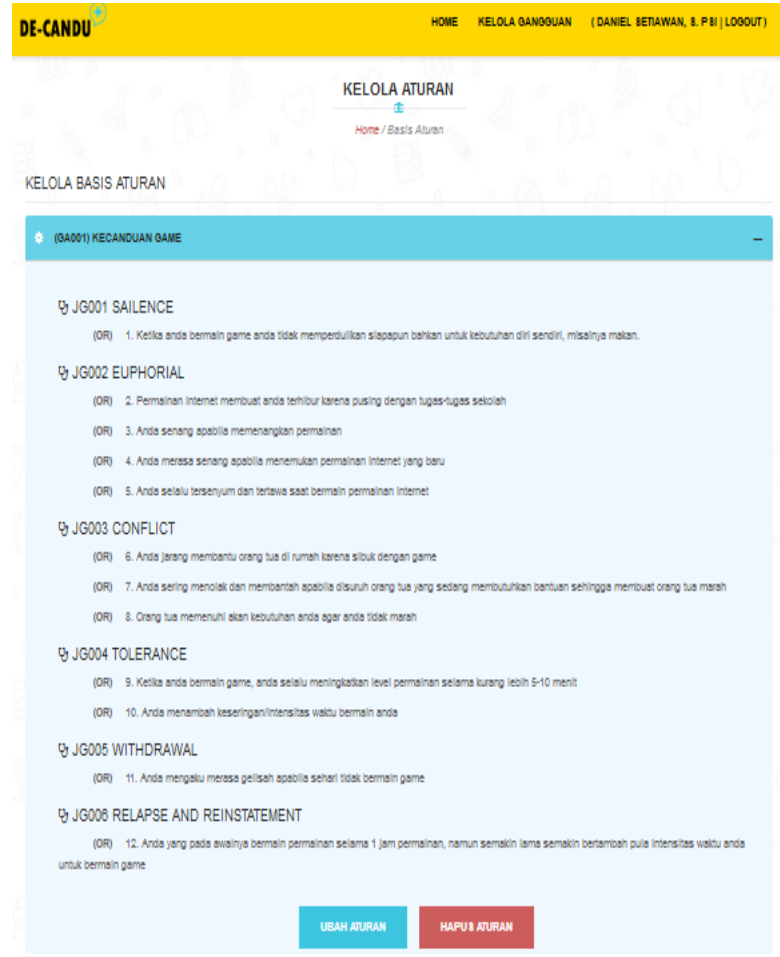

Fig. 4: Page of Manage Rules.

Furthermore, page of guest panel shown in the Figure 5. Guest can access consultation menu to identification game addiction, view consultation report and update profile data. Before guest access this menu, they must register first using registration menu on the main page as shown in Figure 2. 


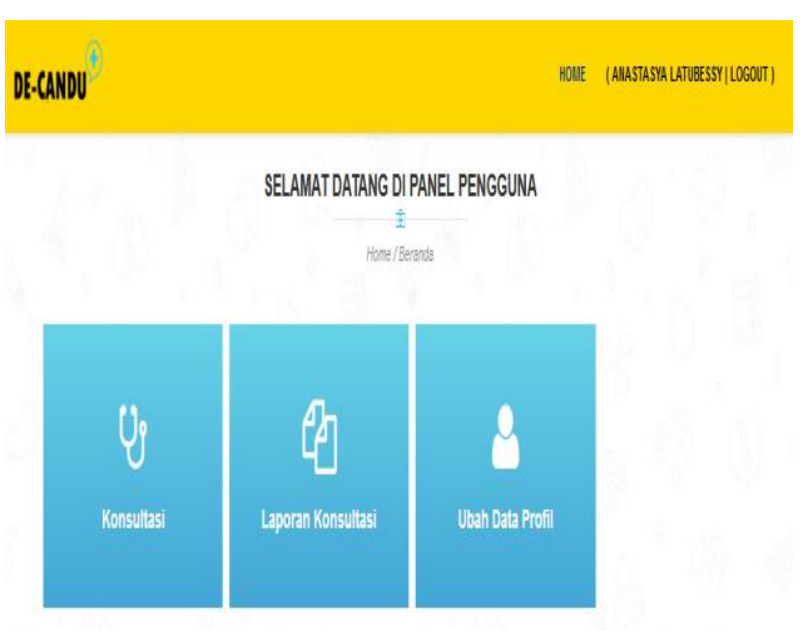

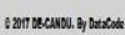

Fig. 5: Page of Guest Panel.

Figure 6 shows a registration form of consultation page. This form used to filled identity of the children. The registration form needs full name, a birth information, and gender. After that click button save to save the data.

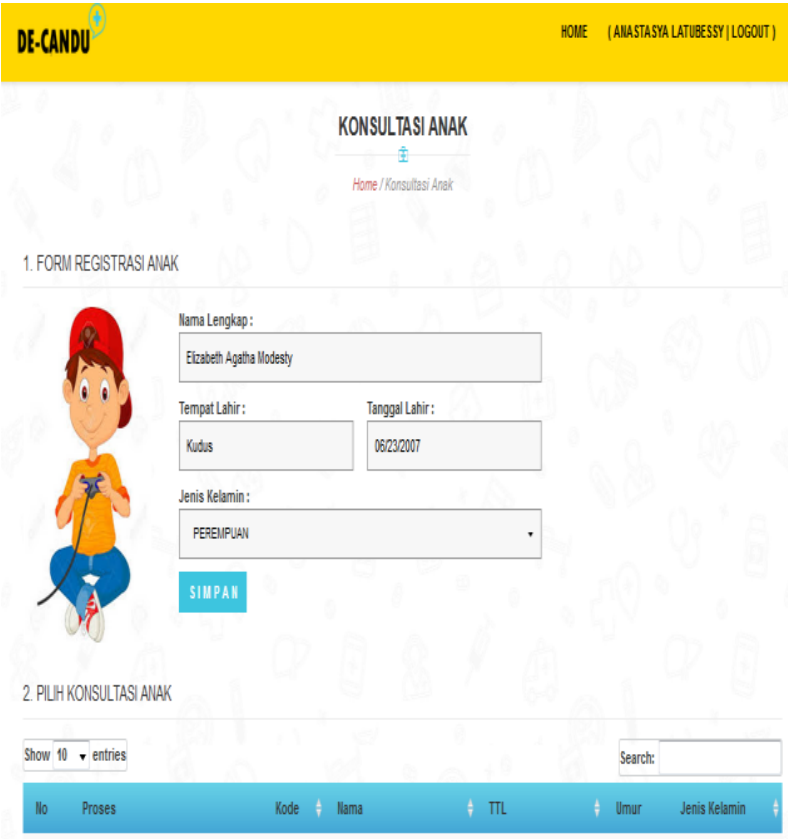

Fig. 6: Registration form of Consultation Page.

Consultation form will be appeared after the registration process. Figure 7 shows a consultation form. There are several statements to identify the game addiction. While Figure 8 shows the next page of consultation form.
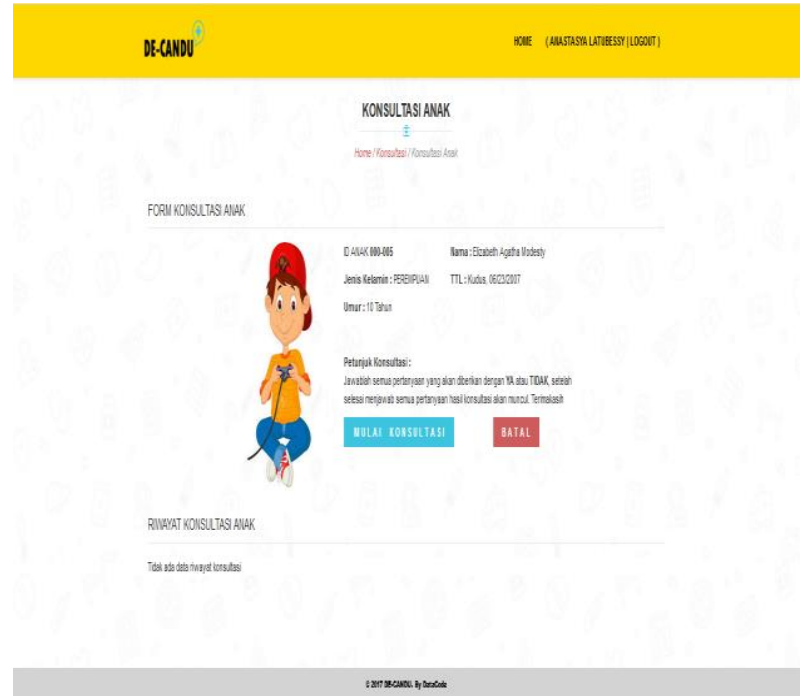

Fig. 7: Consultation Form

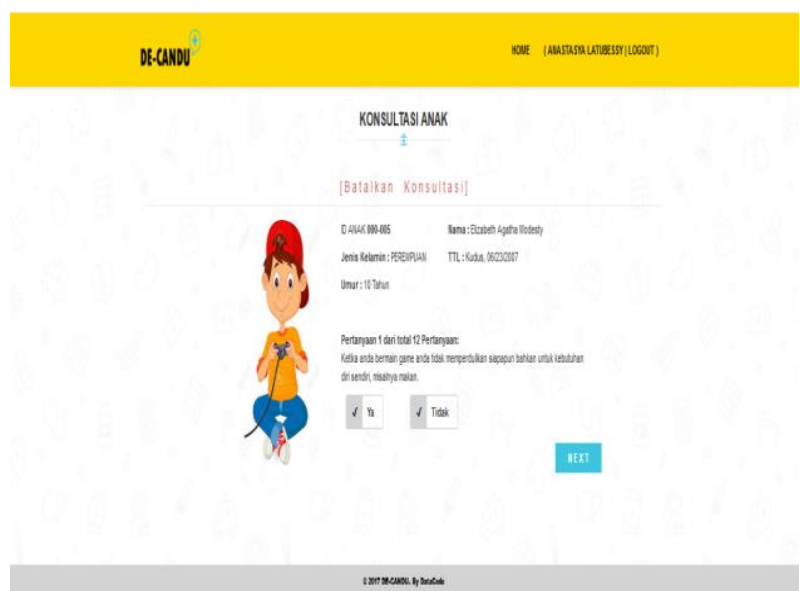

Fig. 8: Next Page of Consultation Form.

After user filling all the statements, then system will processed the answer into backward chaining model and displayed the result as Figure 9. A child is said to be addicted to the game if there are three or more parameters identified.

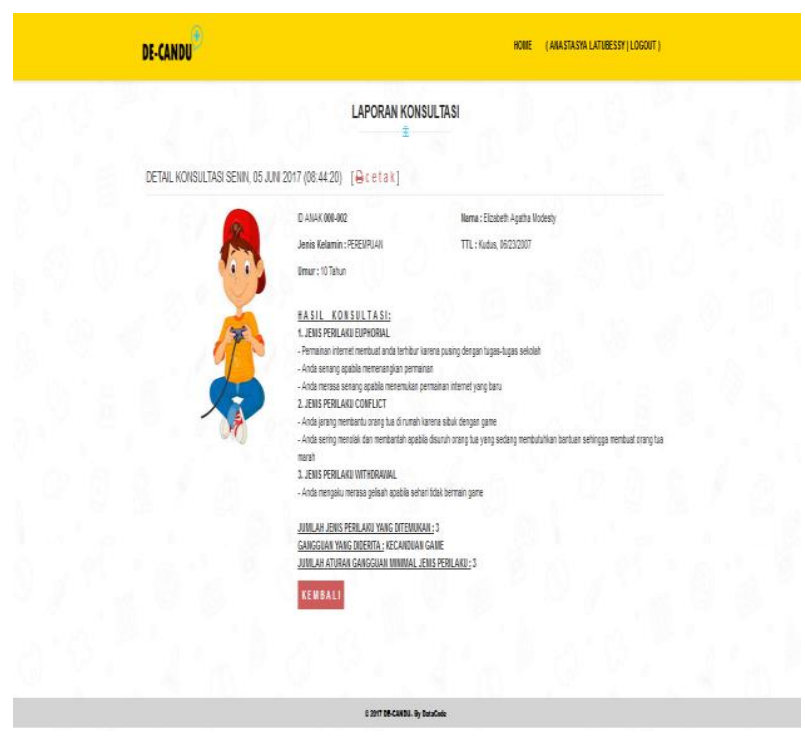

Fig. 9: Result Page.

\subsection{Testing system}

Testing System is done by comparing between manual analysis of experts with application analysis. There are ten data samples 
shown in Table 1. The comparison data in Table 1 shows one discrepancy, which is found in the second data sample.

Table 1: Comparison of Test Result

\begin{tabular}{llll}
\multicolumn{4}{c}{ Table 1: Comparison of Test Result } \\
\hline Sampel & Web Application Results & $\begin{array}{l}\text { Expert Test } \\
\text { Results }\end{array}$ & Compatibility \\
\hline 1 & Not Addicted & Not Addicted & Yes \\
2 & Game Addiction & Not Addicted & No \\
3 & Game Addiction & Game Addiction & Yes \\
4 & Game Addiction & Game Addiction & Yes \\
5 & Not Addicted & Not Addicted & Yes \\
6 & Game Addiction & Game Addiction & Yes \\
7 & Game Addiction & Game Addiction & Yes \\
8 & Game Addiction & Game Addiction & Yes \\
9 & Game Addiction & Game Addiction & Yes \\
10 & Not Addicted & Not Addicted & Yes \\
\hline
\end{tabular}

The data in Table 1 is then used to calculate Single Decision Threshold is done by determining 4 possible decisions, namely:

1) TP (True Positive), where the test results both manually and the application states Normal.

2) FP (False Positive), where the test results manually states suspect but the application states normal.

3) FN (False Negative), where the test results manually declared normal but the application states suspect.

4) TN (True Negative), where the test results both manually and the application states Suspect.

The sensitivity and specificity of the test results is obtained through the following equation.

Sensitivity $=\mathrm{TP} /(\mathrm{TP}+\mathrm{FN}) \times 100 \%$

Specificity $=$ TN $/(F P+T N) \times 100 \%$

Total system performance, obtained through the following equation:

$(\mathrm{TN}+\mathrm{TP}) /(\mathrm{TN}+\mathrm{TP}+\mathrm{FN}+\mathrm{FP}) \times 100 \%$

Based on the data in Table 1, incorporated into the above equations obtained the system sensitivity of $75 \%$, specificity $100 \%$ and Total system performance $90 \%$. Which means the system is in accordance with the expected. The system can be used for game addiction identification process

\section{Conclusion}

A web application has been generated that can be used to identify a child's game addiction rate based on the type of game addiction behaviour. This application uses backward chaining model in fact finding process. Testing system using Single Decision Threshold. The test results are system sensitivity of $75 \%, 100 \%$ specificity and Total system performance $90 \%$.

\section{Acknowledgement}

Ristekdikti supported this research. We thank our colleagues form PPA Anugerah who provided insight and expertise that greatly assisted the research. We would also like to show our gratitude to all for sharing with us during the course of this research.

\section{References}

[1] C. Green, and D. Bavelier, The cognitive neuroscience of video game. Digital Media: Transformations in Human Communication. Messaris \& Humphreys, Eds, 2004.

[2] A.Latubessy and M.N.Ahsin, "Hubungan Antara Adiksi Game Terhadap Keaktifan Pembelajaran Anak Usia 9-11 Tahun", Jurnal Simetris, vol.7, no.2, pp.687-692, 2016 https://doi.org/10.24176/simet.v7i2.782.
[3] A.Latubessy and E.Wijayanti, "Model Identifikasi Kecanduan Game Menggunakan Backward Chaining", Jurnal Simetris, vol.8, no.1, pp. 9-14, 2017. https://doi.org/10.24176/simet.v8i1.807

[4] N. Saquib, etc, "Video game addiction and psychological distress among expatriate adolescents in Saudi Arabia", Addictive Behaviors Reports, December 2017, Vol.6 pp. 112-117. https://doi.org/10.1016/j.abrep.2017.09.003.

[5] O. Lefebvre, "The governance of Internet and game theory", International Journal of Engineering \& Technology, 2018, 7(2.28), doi 10.14419/ijet.v7i2.28.12906.

[6] R. Maskeliūnas, etc, "IDO:modeling a serious educational game based on hands on approach for training dementia Carers", International Journal of Engineering \& Technology, 2018, 7(2.28), doi : 10.14419/ijet.v7i2.28.12898.

[7] A. Latubessy, and A. Jazuli, "Analisis Model Penelusuran Backward Chaining dalam Mendeteksi Tingkat Kecanduan Game pada Anak", Jurnal Teknologi dan Sistem Komputer, Okt 2017, vol. 5, no. 4, pp. 129-134 doi: 10.14710/jtsiskom.5.4.2017.129-134, [Online]. https://doi.org/10.14710/jtsiskom.5.4.2017.129-134.

[8] R.Fiati and A.Latubessy, 2016. "Mapping of Flooded Areas in the Kudus District". Indonesian Journal of Electrical Engineering and Computer Science, 2016, 4(3). doi: http://dx.doi.org/10.11591/ijeecs.v4.i3.pp. 670-677.

[9] B.Yudistira, I.K.G.D. Putra and A.A.K.O. Sudana, "Sketching Expert System for Crime Investigation Purposes". Indonesian Journal of Electrical Engineering and Computer Science. 2014 12(7): 56555660. https://doi.org/10.11591/telkomnika.v12i7.5726.

[10] S.N.Arif, "Implementasi Rule-Based Expert System Dalam Mendeteksi Kerusakan Sistem Jaringan Komputer Dengan Metode Backward Chaining”. Jurnal SAINTIKOM.2011; 10(2): 81-93. 